\title{
The same but different: Understanding entrepreneurial behaviour in disadvantaged communities
}

Thomas M. Cooney

Technological University Dublin, thomas.cooney@tudublin.ie

Michelle Licciardi

Dublin City University

Follow this and additional works at: https://arrow.tudublin.ie/buschmarbk

Part of the Business Administration, Management, and Operations Commons, Entrepreneurial and Small Business Operations Commons, and the Marketing Commons

\section{Recommended Citation}

Cooney T.M., Licciardi M. (2019) The Same but Different: Understanding Entrepreneurial Behaviour in Disadvantaged Communities. In: McAdam M., Cunningham J. (eds) Entrepreneurial Behaviour. Palgrave Macmillan, Cham. DOI: 10.1007/978-3-030-04402-2_13

This Book Chapter is brought to you for free and open access by the School of Marketing at ARROW@TU Dublin. It has been accepted for inclusion in Books/Book Chapters by an authorized administrator of ARROW@TU Dublin. For more information, please contact arrow.admin@tudublin.ie, aisling.coyne@tudublin.ie, gerard.connolly@tudublin.ie.

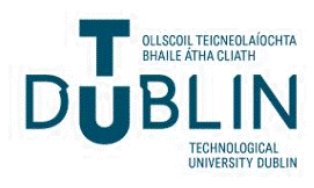




\section{The Same but Different: Understanding Entrepreneurial Behaviour in Disadvantaged Communities}

\section{Introduction}

It is broadly agreed that the origins of entrepreneurship theory stem from an economics background. Early literature on the topic identified the entrepreneur as risk-taker, innovator, supplier of financial capital, decision-maker, industrial leader, co-ordinator of economic resources, employer of factors of production, and proprietor of an enterprise. In more recent times the work has diversified to include differing schools of thought that have their foundations in areas such as management, psychology, and sociology. Some commentators would suggest that Gartner (1989) altered the traditional discussion concerning entrepreneurship from a focus on the person to an examination of the behaviour of the entrepreneur. Gartner contended that an entrepreneur was someone who identified a business opportunity, accumulated resources, marketed the product or service, and created an organisation. Bygrave and Hofer (1991) extended this contention by highlighting the notion of entrepreneurship as a process which involves all functions, activities and actions associated with perceiving opportunities and the creation of organisations to pursue them. They further suggested that entrepreneurship does not occur unless there is a risk of losing personal capital. It was broadly assumed within these discussions that all entrepreneurs (of whatever background) will go through similar experiences of entrepreneurial behaviour.

According to Schumpeter (1934), an entrepreneur is someone who carries out new combinations. Schumpeter described entrepreneurship as 'creative destruction', whereby established ways of doing things are destroyed by the creation of new and better ways. He suggested that an entrepreneur seeks to reform or revolutionise the pattern of production by exploiting an invention or by opening-up a new source of supply of materials or a new outlet for products. He believed that an entrepreneur was someone who gathered resources, organised talent and provided leadership. It could be argued that the three driving forces of entrepreneurship of opportunity, resources, and team in the Timmons Model (see Timmons, Spinelli \& Tan; 1994) are akin to Schumpeter's concept of an entrepreneur. Likewise, Drucker (1985) viewed entrepreneurship as occurring when resources are redirected to progressive opportunities, not to ensure administrative efficiency. However, when one considers these interpretations, it could be questioned if entrepreneurship is equally accessible in all contexts and if potential or nascent entrepreneurs from non-mainstream society experience entrepreneurship in a similar manner.

Until the early 1980s, adult males were the primary focus of research relating to entrepreneurship (Watkins and Watkins, 1984). Other profiles or communities were so peripheral to studies that 
employment figures were not even recorded for females until recent decades. Stevenson and Lundstrom (2001) claimed that the use of inclusion policy was a potential solution to the marginalisation experienced by minority and disadvantaged communities and they distinguished the different ways a government can stimulate entrepreneurship amongst under-represented groups. Their proposed targeted policy measures included: creating enterprise centres, promotion activities, entrepreneurship awards, counselling, training and advisory support. It was suggested that through these policy initiatives, minority and disadvantaged communities could be better equipped to overcome the entrepreneurship challenges they endure which differ from those experienced by mainstream society.

While the term 'minority entrepreneur' is used significantly in the literature, its meaning can be quite varied as sometimes it is used to reference immigrants, other occasions it relates to ethnicity, while more generally it is used to describe people from communities who are under-represented in terms of entrepreneurial activity. Similarly, the term 'disadvantaged' can have many interpretations and so finding a common understanding relevant to entrepreneurship can be challenging. In recent years, the OECD has published a series of reports called 'The Missing Entrepreneurs' (OECD 2013, 2014a, 2015, 2017) which have sought to identify the key challenges faced by potential and nascent entrepreneurs from minority and disadvantaged communities, and these reports offer recommendations that policymakers could undertake to help reduce existing challenges for 'missing entrepreneurs'. In these reports, the 'missing entrepreneurs' have been identified as belonging to the following communities: Women, Youth, Seniors, Unemployed and Immigrants. Galloway and Cooney (2012) highlighted the adversities facing 'silent minorities' and identified Gay, Disabled, NEETs (Not in Education, Employment or Training) and ExOffender communities as being disadvantaged in terms of entrepreneurial behaviour. Wood et al (2012) identified eight 'minorities in entrepreneurship' which included Indigenous entrepreneurs (e.g. Aborigine, Maori) amongst those communities that have already been mentioned above. Therefore, to consider entrepreneurial behaviour amongst minority or disadvantaged communities involves a broad array of communities and selecting those worthy of discussion for this chapter was challenging. The communities selected for analysis were those ones which were considered of most value to the book because additional knowledge would be contributed to the overall learning presented across the various chapters. In discussing the different communities, some broad conclusions have been generated concerning the additional and distinctive challenges faced by minority and disadvantaged entrepreneurs when starting their own business and recommendations offered regarding how policymakers might respond. 


\section{Immigrant Entrepreneurship}

Over the past twenty years, the term Immigrant Entrepreneurship has been used interchangeably with Ethnic Entrepreneurship, Minority Entrepreneurship and several other terms when discussing the entrepreneurial behaviour of immigrants (Carter et al., 2015). Chrysostome and Lin (2010) asserted that Immigrant Entrepreneurs (IEs) cannot be analysed and researched as a single homogeneous group of entrepreneurs since they come from various cultural backgrounds and have a range of reasons for starting a business. The Global Entrepreneurship Monitor (GEM) Report (2016) identified opportunity entrepreneurs (OEs) and necessity entrepreneurs (NEs), whereas Chrysostome and Lin (2010) categorised opportunity-driven immigrant entrepreneur (ODIEs) into four different categories: global immigrant entrepreneurs, traditional or ethnic opportunity entrepreneurs, transnational immigrant entrepreneurs and diaspora entrepreneurs. Furthermore, Reynolds et al. (2002) concluded that different types of immigrant entrepreneurs will have a different influence on the host country's economic development, monetary gains and entrepreneurial outcomes, and therefore the variances in entrepreneurial behaviour across assorted ethnic groups needed to be understood.

Recent studies on immigrant entrepreneurship have focused on the various influences involved, such as their education in their home or host country (Peroni et al., 2016), previous entrepreneurial endeavours in either location and level of management achieved (Fatoki, 2014), length of residency in their host country (Wang and Warn, 2017), the degree of integration (Bhachu, 2017), forms of capital (Dodd et al., 2016), rural or urban setting (Tamásy and Diez, 2016), ethno-cultural factors (Lai et al., 2017), role of enclaves (Andersson and Hammarstedt, 2015) and power of the diaspora (Elo et al., 2018). Such a list of topics illustrates the breadth of influencing factors relating to immigrant entrepreneurship and the challenges facing policymakers when seeking ways to engender greater levels of entrepreneurial activity from within immigrant communities. Shinnar and Young (2008) asked if there should be a deeper exploration of motivations (the widely discussed push or pull factors) when exploring immigrant entrepreneurship, while Ndofor \& Priem (2011) wondered if greater examination should be given to the function and power of ethnic enclaves. Indeed, such is the complexity of the topic that one could argue that more than economic and business research is required, and that other scientific researchers (such as anthropologists and sociologists) should also be part of immigrant entrepreneurship studies. Assessing where greatest value can be offered, either in terms of research or policy, remains a challenging proposition within this topic.

It should be noted that the rate of entrepreneurial activity by immigrants is generally greater than found amongst the native population (Naudé et al., 2015). An OECD (2011) study of all OECD countries 
found that the percentage of immigrant entrepreneurs starting a business is higher than for natives (12.6 percent versus 12.0 percent), but the survival rate of immigrant-owned businesses is lower than the figure for businesses started by native-born entrepreneurs. The study also found that an immigrant entrepreneur who owns a small or medium firm creates between 1.4 and 2.1 additional jobs, slightly less than their native-born counterparts (1.8 - 2.8). According to Desiderio and Salt (2010), the general approach by policymakers is to help immigrant entrepreneurs through mainstream business support programs and simultaneously offer some targeted and structural policies to create an environment conducive to immigrant entrepreneurship. However, such approaches do not recognise the distinctive challenges faced by immigrant entrepreneurs, such as reduced access to finance, poor language capabilities, lack of networks, issues of trust with local population, limited understanding of local ecosystem, racism and low managerial experience due to blocked mobility (Deakins et al., 2007; Masurel et al., 2004). Furthermore, every country is different in terms of its physical, economic, social, cultural, environmental and political characteristics (as are the countries of origin), which means that nascent immigrant entrepreneurs are emerging across diverse environments and their motivations, level of innovation, start-ups and endurance must be considered within their different contexts. Some researchers have proposed a mixed embeddedness framework (e.g. Jones et al., 2014) to underpin the factors prompting immigrant entrepreneurs and have suggested that such an approach might inform policymakers regarding the nature of the support that can be provided to maximize the potential of immigrant entrepreneurs.

The European Commission (2016) published a guidebook titled 'Evaluation and Analysis of Good Practices in Promoting and Supporting Migrant Entrepreneurship' which proposed the essential components required for the successful promotion of Immigrant Entrepreneurship. These were structured into ten dimensions (Visibility, Networking, Legal and regulatory advice, Individual business support, Group business training, Mentoring, Access to finance, Facilities provision, Language and cultural sensitivity and Impact) and practical suggestions were presented with each dimension. It was argued that the multidimensionality of the support provided is fundamental to successful outcomes and broadly this should comprise of three extensive dimensions: competences and skills development, provision of social capital and tangible needs. The evaluation of good practices also established that cohesively blending several complementary supports will empower nascent immigrant entrepreneurs to circumvent the gamut of barriers encountered in starting-up, managing and expanding their businesses in their host country. Cooney and O'Flynn (2008) highlighted that policymakers frequently do not understand the additional and distinctive challenges faced by immigrant entrepreneurs and commonly believe that 
ensuring that immigrants have access to mainstream supports is enough to satisfy their needs in terms of engendering entrepreneurial behaviour. They also regularly fail to recognise the substantial potential that immigrant entrepreneurs conceivably offer in terms of export activity and transnational diaspora entrepreneurship. If immigrants were viewed as an economic resource rather than as a social problem, then the true prospective value might be given greater recognition by politicians and policymakers.

\section{People with Disability}

According to WHO (2011), approximately 15 per cent of the world's population live with some form of disability, but Cooney (2008) has highlighted that their rate of employment and pay is very poor relative to people without disability. Despite this global problem of people with disability securing gainful employment, the study of entrepreneurial behaviour for people with disability has been scant. It is curious why more studies have not been undertaken on this topic given the size of the community, particularly as Grandin and Duffy (2008) observed that self-employment allows people with disability to focus on their strengths and working preferences. Self-employment also permits improved accommodation of their disability and if successful can result in their increased social and economic emancipation. According to Meager and Higgins (2011) and Pagán (2009), self-employment for people with disability may well offer the capacity to self-manage suitable tasks whilst working in a manner, location and within timeframes that do not add to the challenges of a person's ability to work. However, Meager and Higgins (2011) and Lechner and Vazquez-Alvarez (2011) emphasised that the type and gravity of a disability and the impairment physiognomies directly affects the levels of participation, types of occupation and potential income. Jones and Latreille (2011) attributed pull factors to the motivations behind people with disability engaging in entrepreneurial behaviour, but Foster (2010) ascribed it to push factors. Some recent studies have sought to explore the criteria and influence on entrepreneurial behaviour for people with disability (e.g. Rozali et al., 2017), but to date much of the research has been fragmented and with limited sample sizes.

In seeking to understand the distinctive challenges faced by people with disability engaging in entrepreneurial behaviour, research studies by the OECD (2014b) and Kitching (2014) have identified the principal barriers as follows:

- Access to finance, the application processes and bureaucratic difficulties;

- The knock-on effect of illness and stress which directly influences a person's readiness and capacity to commit; 
- Information about enterprise supports and the fact that they may not be adequately tailored towards or reaching the targeted population;

- Lack of business knowledge, skills and access to business networks which are more prevalent amongst people with disability than for people without disability for a number of underlying and cross-cutting reasons;

- The absolute fear of losing benefits and the impact it will have on their ability to pay housing and medical costs;

- Absence of applicable and perceptive business supports and the lack of comprehension of the range of disabilities and additional disadvantages a person may be facing.

Kouriloff (2000) contended that it is a combination of psychological, socio-cultural and political barriers that deters disabled people from starting a business, whereas Parker Harris et al. (2014) suggest that concerns by family and friends is a reason people with disability may have a real fear of failure, in addition to having doubts about their entrepreneurial experience, a lack of management skills and poor financial mastery. Renko et al (2016) found that the barriers that people with disability face in other societal domains may also hamper their entrepreneurial entry and that nascent entrepreneurs with disabilities are significantly less likely to emerge from the firm gestation process as owners of operating businesses. The results of these studies endorse the perspective that the additional and distinctive challenges faced by people with disability have a negative impact on their entrepreneurial behaviour.

For the situation to change, policymakers must appreciate the heterogeneity of disability impairment characteristics if appropriate and effective solutions to these obstacles are to be implemented. The OECD (2014b) found that many enterprise support agencies are not perceived to be disability-inclusive, disability aware, disability-sensitive or disability-supportive, plus they highlighted that few agencies proactively target people with disabilities. The study also identified that not all enterprise support agencies have it within their remit to support people with disability, while those who have it within their remit are frequently not actually making any real or lasting impact. While disability policies theoretically reflect the fact that self-employment is a viable and sometimes preferred option for people with disability, the European Commission (2015) reasoned that the sustainability of businesses by entrepreneurs with disabilities may not always be an appropriate objective for public policy because supporting low-value added businesses in highly competitive industries may only delay an inevitable business exit. Indeed, Renko et al (2016) found that enterprises found by people with disability are less likely to result in the emergence of a viable organization than the efforts of those who are not disabled. The European Commission further contended that when policymakers do intervene, they should prioritise 
interventions that increase the entrepreneurs' skills levels so that they have a better chance of finding employment if their business does not survive. Some researchers concede that new supports are not necessarily required, but instead they should be "disability proofed" by experts and users, be inherently adaptable and customisable to the needs of the wide range of different types of disabilities (Doyel, 2000). McQuillan (2012) advocated that any self-employment initiatives for people with disability should incorporate a universal set of success factors such as: Project Advocates and Champions, Person-Centred Planning, Generating Business Ideas Based on Interests, Supports, Peers as Role Models, Openness to Risk and Failure, Viewing Self-Employment as an Option, Self-Confidence and Inclusion, plus Building on Local Resources, Networks and Enterprise Supports. McQuillan emphasised that the current targeting and promotions of programmes suffered from a lack of pre-startup confidence building training for beneficiaries, insensitive or untrained advisors, a dearth of networking support, poor dissemination of good practice and a lack of showcasing of success stories. Indeed, there have been some demands for more involvement and mentoring from successful entrepreneurs (both mainstream and entrepreneurs with a disability) and the creation of a forum for a peer support network (Maritz and Laferriere, 2016).

Overall, it could be argued that any new entrepreneurship initiatives for people with disabilities will require real commitment and connected, open minded thinking; not necessarily new specific programmes, just a more informed, sensitive approach. The availability of specialist equipment made available through outreach support programmes and disability 'hotspots' where peers can meet each other and advisers would also be very helpful. Stakeholders may need to agree that the barriers are widely acknowledged and that it is now time for policies to be implemented in conjunction with leading best practice and an evaluation process. Differences in impairment characteristics should influence policy attempts to involve and support these entrepreneurial capabilities, as each disability category (intellectual, physical, mental, sensory) demands different forms of support. New initiatives may also need to determine why there is an overreliance on social welfare benefits, progression schemes and voluntary community-based schemes and it also may be necessary to establish why it seems to be so difficult to offer tailored support around individual requirements and spectrums. Larsson (2006) found that in Sweden, entrepreneurs with disabilities were more likely to work part-time on their businesses because of the nature of the challenges that they face, but this form of entrepreneurial behaviour can be changed given appropriate support. However, the limited availability of research on the topic has meant that policy regarding entrepreneurship for people with disability (as opposed to labour market participation) is a recent enough phenomenon and has resulted in multi-layered and sometimes conflicting policies across different government departments, and occasionally incompatible objectives and desired outcomes. 


\section{Youth}

In January 2018, 3.646 million young persons (under 25) were unemployed in the EU28 which meant that the youth unemployment rate was 16.1 per cent compared with 17.6 per cent in January 2017 (Eurostat, 2018). Given that almost 74 million young people (aged 15-24) were looking for work globally in 2014 (GEM, 2015), some researchers (e.g. Bertelsmann Stiftung, 2016) argued that the impact of longterm unemployment can scar youth with negative outcomes on their physical and mental well-being. They also suggested that long-term unemployment damages their trust in society and adversely affects their prospects of employment, thereby increasing the risk of social exclusion. The substantial level of youth unemployment across the globe in recent times has created an unprecedented challenge for policymakers and future forecasts validate the need for an immediate, robust and coordinated solution. Academics, practitioners, policymakers and enterprise support agencies have been urgently examining youth entrepreneurship in order to propose policy approaches and frameworks for the development of relevant initiatives at national, regional and local levels. Given the scale of the problem, it is arguable that youth entrepreneurship policy requires revolutionary and comprehensive action plans and timeframes, plus they must be inclusive and be capable of engendering entrepreneurial behaviour amongst young people.

Knowledge focused specifically on the entrepreneurial behaviour of young people is still comparatively limited due to gaps, contradictory findings and the deficiency in evidence on impact and outcomes. Much of the early research on youth entrepreneurial behaviour tended to treat young individuals like their older counterparts (Lewis and Massey, 2003), and so policymakers habitually missed guidance on matters regarding whether unique advisory and support initiatives should be developed for the young versus the old (Minola et al, 2014). Listerri et al. (2006) asserted that youth entrepreneurship has benefits other than self-employment because it directly results in increased levels of conversion into paid employment within three years in comparison to the disappointing transition outcomes from unemployment. However, Ceptureanu and Ceptureanu (2015) noted that young people face specific challenges preventing some youths from turning ideas into business and that these challenges include social attitudes, lack of skills, inadequate entrepreneurship education, lack of work experience, lack of capital, lack of networks and market barriers. Research by the OECD (2017) found that approximately twothirds of youth view entrepreneurship skills as a barrier to business creation, whilst almost half of young people in the European Union say that fear of failure is a major barrier to entrepreneurship.

It has been suggested that NEETs (Not in Education, Employment or Training) will face the same obstacles of all youth entrepreneurs, but that the magnitude and after-effects of their situation is much 
more serious for society. According to Eurofound (2011), NEETs are also more likely to be disabled, have a migrant background, have a low level of education, live in remote areas, have low household incomes and have parents who experienced unemployment. This category has proven to be the most resistant to all policies and programs (particularly those initiatives seeking to alter low levels of skill and capital) and has led to global discussions amongst stakeholders as to whether policy should focus on those with the greater chances of success or those with the greatest needs, although ignoring NEETS will have significant future costs and consequences. Therefore, a distinction needs to be made between disadvantaged youth (unemployed, inactive, marginalized environment, significant gaps in financial, human and network capital, role models and family support) and other youth. An OECD (2010) report titled 'Shooting for The Moon' offered some guidelines on good practice criteria in local youth entrepreneurship and can be used as a tool to self-assess and re-orientate strategies, structures and practices. It also sub-divides support into three dimensions (opportunity creation, entrepreneurship education and start-up support) which is very helpful for policymakers in terms of resource allocation.

Increased entrepreneurial behaviour by young people cannot single-handedly solve youth unemployment but it most certainly has a vital role to play in assisting entry into the labour market for youth with the drive and determination to become entrepreneurs. When designed appropriately, government policies and programs can empower youth to contribute and feel included in society, plus enable them to start on the road to economic independence and increased self-esteem. Governments benefit from the reduction of pressure on the exchequer, increased revenue and the multiplier effect that the harnessing of this aptitude, passion and social energy provides to a country in today's fast-paced and competitive economic environment. There is an awareness that policy initiatives must also engender the development of 'soft skills' and increasingly policy documents include specific and measurable actions relating to the development of such skills. Generally, the key to success is how governments implement such policies, the accompanying budget they provide to support these policies and how the policy guidelines are adopted in a collaborative approach by a diverse range of stakeholders.

\section{Gay Entrepreneurship}

Wood et al. (2012) suggested that one of the reasons for the omission of gay people from the study of entrepreneurship was due to other areas (such as human rights) being prioritised by researchers. Gay people are narrowly understood in terms of entrepreneurial behaviour with early discussions probing their distinction from heterosexual entrepreneurs (Lukenbill 1995; Levin, 1998; Varnell, 2001), although more expansive work has begun to develop in the field in recent times (Redien-Collot, 2012; Marlow et 
al, 2018). The literature suggests that the emergence of the 'pink pound' (Fry, 1997; Wood, 1999) led to a new level of investigation of gay people as the market gained a strong reputation for having strong spending power (Branchik, 2002; Sender, 2004; Buford, 2005). The value of the gay market has been suggested as having positive implications for the visibility of the community (Chasin, 2000) and this is arguably the case for gay entrepreneurs who originally appeared in research about the gay market (Lukenbill, 1995). With the rising financial interest in the gay community, the demand for solid market information increased. Reports and articles began to appear on the topic (e.g. Lukenbill, 1995; Fry, 1997; Kates, 1998; Wood, 1999; Chasin, 2000), eventually leading to studies relating to the entrepreneurial behaviour of gay entrepreneurs.

While an entrepreneur who is gay may experience greater incentives for starting a business due to career issues such as blocked mobility, they will certainly endure greater challenges to self-employment than experienced by heterosexual entrepreneurs (Kidney and Cooney, 2014). In addition to meeting the conventional difficulties that any entrepreneur experiences in starting a business, a gay entrepreneur must also overcome complex problems such as prejudice and discrimination in the market place, and in the pursuit of enterprise support and venture capital (Kidney and Cooney, 2014). Furthermore, institutional inequality exacerbates cultural marginalisation (Baker et al., 2004), albeit membership of the gay community increases in-group salience and identification which can deconstruct homophobic behaviour through solidarity. Early research by Levin (1998) suggested that a gay entrepreneur was likely to target the gay community for custom or to identify a niche opportunity for gay products/services. This form of entrepreneurial behaviour is akin to that found amongst immigrants, although the gay market is frequently larger and wealthier than many immigrant communities. Levin also identified that gay-owned businesses were contributing positively to the gay community, while Schindehutte et al. (2005) submitted that their entrepreneurial behaviour was frequently considered as 'giving back'.

Government institutions which have been influenced by religious philosophies frequently do not provide equal benefits to gay people. Heterosexual married couples can take advantage of tax benefits, but this assistance is not available to gay couples who live in countries where civil unions or gay marriage are not legal. Regardless of how long a gay couple have been in a partnership, their rights as a significant other are overlooked and even frowned upon by conventional political parties. Many countries provide tax incentives for employing a spouse and this relief can make a significant difference when hiring the first employee in a new business. Unfortunately for a gay entrepreneur, life partners cannot gain from this tax break in countries where gay marriages are not recognised. The constitutional rejection of gay rights to the same benefits that heterosexuals receive negatively influences the entrepreneurial behaviour of gay 
entrepreneurs as it places additional and distinctive challenges to starting (or selling) a business that the heterosexual community does not endure. Feelings of self-doubt or low self-esteem caused by societal intolerance can also increase a gay person's perception of risk and will have a negative effect on entrepreneurial behaviour within the community. On the other hand, institutional discrimination can also act as a 'push' factor and inspire people to break prejudicial traditions by profiling their strength and success as an entrepreneur. Yet, the negative effects of institutional discrimination prevail over the positive, leaving a durable impediment regarding entrepreneurial behaviour in the gay community. For example, Wilkinson and Kitzinger (1994) discussed how members of the majority population possess 'safe' and 'uncontested' identities and that this dominant group feels no need to assert itself or claim its heterosexuality. Therefore, heterosexuals have no need to 'come out of the closet' or confess to their parents that they are straight, but a gay entrepreneur faces the dilemma of deciding whether to 'come out' as a business, a facet of entrepreneurial behaviour that is greatly underexplored in the literature. Inevitably, there are some advantages and disadvantages to identifying a business with its owner's sexuality as business from within the gay community may increase as gay consumers may feel more appreciated and accepted, but such a business also runs the risk of enduring religious boycotts, stigma and hate crime in a hostile environment. They are frequent instances of homophobic graffiti littering the walls of businesses owned by gay entrepreneurs (Kidney and Cooney, 2014) and in such environments it is not advantageous for a gay entrepreneur to express their sexuality and this causes them to alter their entrepreneurial intentions and behaviour.

It has also been suggested that groups that suffer discrimination (such as minorities) generate proportionately more entrepreneurs than mainstream communities (Bridge et al, 1998) and certainly there is evidence that gay people find it more difficult to gain and sustain employment (Tilcsik, 2011). Therefore, it is arguable that a gay person does not overcome the barriers to entrepreneurship willingly, but out of necessity and in response to rejection from the greater society. Willsdon (2006) highlighted that policymakers assume gay entrepreneurs cannot be researched as it is uncommon for members of the gay community who are self-employed to distinguish themselves from heterosexuals at this level. However, to generate higher levels of entrepreneurial activity from within the gay community, the business environment needs to understand the benefits, challenges, barriers and incentives exclusive to gay people. Indeed, understanding the factors that distinguish entrepreneurial behaviour amongst gay business people from heterosexuals can lead to the development of a comfortable environment to foster gay entrepreneurial activity. For example, one potential solution for overcoming the barriers to entrepreneurship is the establishment of a gay enterprise zone, areas that can be found in many major 
cities such as London, Paris and San Francisco. Although this solution cannot offer a resolution to problems such as institutional inequality, an enterprise zone such as the gay 'ghetto' in the Marais district of Paris can profile the gay lifestyle as a common way of life (Kidney and Cooney, 2014) and thereby 'normalise' activities such as entrepreneurial behaviour. In addition to the social implications of promoting equality, the economic benefits offered to the gay entrepreneur are substantial as gay consumer demand can be met more appropriately with gay supply. The 'gay ghetto' offers a relaxed and affluent market place in which a gay entrepreneur can start-up without facing many of the barriers perceived in greater society. Castells (1983) detailed the 'transition from the bars to the streets, from the night time to day time, from 'sexual deviance' to an alternative lifestyle' which transformed areas of Paris into self-sustaining gay communities. Krugman (1996) observed that such transformation occurs when a population grows so that it is enough to foster and sustain a gay district. Krugman described how an economic benefit of the appearance of a gay urban space is the further creation of secondary businesses, thus gay business becomes a self-replicating entity with the potential to also encourage entrepreneurial behaviour amongst other communities. While the concept of gay business districts creates opportunities for gay people (having access to market opportunities), there is also a risk of ghettoization which may cause the need for 'break-out'. This term has been used in research relating to the entrepreneurial behaviour of ethnic minorities to describe their move from community-serving businesses to more mainstream businesses (Waldinger et al., 1990).

According to Prince (1997), young gay people are increasingly able to make career decisions consistent with their sexual identity development, thereby enabling them to choose a working environment in which they will feel as accepted as their heterosexual counterparts. In some cities, a gay person can choose to work in an environment where the gay community is the majority, such as a gay 'ghetto'. As policy measures worldwide begin to increase the level of promotion which entrepreneurship receives in the economic ecosystem and with the escalating number of countries who legally recognise same sex marriages, there is ever greater awareness amongst the young gay people of the benefits of starting their own business. While young gay people may sometimes leave employment because of the 'lavender ceiling' effect (Willsdon, 2006), having suffered such homophobia in their place of work, selfemployment can become the most attractive path for economic advancement. But an individual's response to discrimination can differ from person to person (Willsdon, 2006) and this will influence how they engage in entrepreneurial behaviour. People who may consider themselves to be treated as peripheral to society may choose not to reveal their real identity, while others may become an entrepreneur to avoid being treated differently in the workplace (Scase \& Goffee, 1980). It is arguable 
that independence through entrepreneurship can allow a person from a marginalised group to evade persecution at the hands of mainstream idealism. This suggests that traditional rewards such as status, independence, wealth and empire building are augmented for the gay person, as freedom from perceived and real discrimination creates an additional motivation for self-employment. Therefore, independence from social exclusion is arguably a powerful motivational actor for entrepreneurial behaviour within the gay community.

\section{Unemployed}

The economic recession of 2008 caused a dramatic increase in rates of unemployment across the globe. Eurostat (2018) found that unemployment steadily increased between the second quarter 2011 until the second quarter of 2013, taking it to a record level of 26.5 million people unemployed in late 2013. However, in recent years the rate of unemployment in many countries has generally been falling and employment levels are now returning to pre-economic recession levels. The rate of unemployment in EU countries in April 2018 was 7.1\%, which Eurostat (2018) estimated is 17.462 million men and women in the EU28. Fritsch et al (2015) found that new business formation is higher during recessions than in boom periods, but they found that the effect of unemployment on new business formation is only statistically significant if the level of unemployment is below the trend. The European Commission (2016) highlighted that long-term unemployment can lead to a deterioration of skills and human capital, thereby hindering one's capabilities relevant to entrepreneurial behaviour. The European Commission also observed that despite much research, policy triggers and programs, fewer than $5 \%$ of unemployed people across the EU transition into self-employment each year and globally the figures remain lower than predictions, while the OECD (2017) determined that there is a higher risk of displacement (whereby a business captures customers from another business, so there is no net economic benefit) with businesses started by unemployed relative to those started by the mainstream population. Therefore, it is suggested that public policy measures should favour start-ups with innovative ideas and the European Commission (2016) has published a policy framework, underpinned by a policy agenda and an emphasis on 'what works', that can be utilised to encourage long-term unemployed to launch sustainable and profitable enterprises.

While encouraging long-term unemployed people to start a business might appear a positive intervention, caution is advised as Block and Koellinger (2009) established that 'unsatisfied entrepreneurs' includes individuals starting a business after a period of long-term unemployment and those individuals with a lack of better employment alternatives (i.e. necessity entrepreneurs). But research from the European Working Conditions Survey (2015) accentuated the promise of entrepreneurship for 
unemployed people by focusing on their potential to contribute to innovation, job creation and economic sustainability, with Caliendo, Fossen and Kritikos (2014) finding that regional factors, the rural/urban divide and motivation all influencing the entrepreneurial behaviour of the unemployed. However, policymakers are generally grappling with the degree of multiplicity in the findings on unemployed people who have launched businesses and the accountability of 'push versus pull' factors. Much of the recent discussion by policymakers has been related to the type of unemployed people that have become entrepreneurs, whether they are creating jobs and which industries they are entering. Policymakers are also keen to learn if such entrepreneurial behaviour leads to 'genuine self-employment' or if it is a form of 'economically dependent self-employed or bogus self-employed' with only one client and with the blurring of boundaries between employee and self-employed status. Overall, policymakers are struggling to develop appropriate initiatives as there is a scarcity of evidence explaining the entrepreneurial behaviour of unemployed people despite their significance to the economy.

An OECD (2017) report highlighted that policymakers need to be aware that engaging in entrepreneurial behaviour (although a major priority on the agenda) is not a solution for all unemployed people. Zouhar and Lukes (2015) found that nascent entrepreneurship of unemployed individuals was lower for females, youths and people with lower education. They also confirmed the negative impact of unemployment benefits on solo entrepreneurship, but they found a positive influence between active labour market policies and entrepreneurial behaviour that plans to create jobs. It is also imperative that policymakers are cognisant of the detrimental effects of business failure on a cohort of people that are already vulnerable, as Boyce et al. (2015) found that unemployed men and women experienced significant patterns of change in their mean levels of agreeableness, conscientiousness and openness, whereas reemployed individuals experienced limited change. The results indicated that unemployment has wider psychological implications than previously thought and therefore will have greater impact on entrepreneurial behaviour than formerly understood. In accordance with the European Pillar of Social Rights (2017), inclusive entrepreneurship policies and programs can equalise discrepancies in society and change outcomes, but the types and level of support will directly influence the entrepreneurial behaviour of unemployed people and the impact that such initiatives have towards engendering sustainable businesses. Researchers and academics concur that international best practice is to ensure that the entrepreneurial support is presented in a phased manner and can co-ordinate with other agencies to build capacity and address the multiple factors that led to unemployment. Entrepreneurship is theoretically a source of job creation for both short and long-term unemployed people and can significantly decrease 
negative outcomes if substantiated by joined-up and carefully considered active labour market policies and programs.

\section{Conclusion}

The review of the literature offered insights into the additional and distinctive challenges faced by entrepreneurs from different minority and disadvantaged communities in comparison to entrepreneurs who emerge from the mainstream population. These communities face many similar challenges while other challenges are specific to certain communities. It is evident that the way society views these communities has a significant influence on their entrepreneurial behaviour, specifically with reference to the prejudice and discrimination that each community endures in terms of gaining employment which frequently leads to starting a business. Unfortunately, many of these communities also experience the 'glass ceiling effect' in terms of career advancement and this frequently engenders entrepreneurial behaviour. Both the prejudice and discrimination regularly continue into self-employment as was apparent across all communities, but additional common challenges were also evident. Access to finance was a major challenge for each community as many were unable to accumulate their own capital due to their inability to secure high-paid employment (or any employment). The glass ceiling also affected people's ability to secure managerial experience which is a welcome attribute to possess when starting a business. Furthermore, there was much evidence to demonstrate that enterprise support agencies generally do not understand that these communities have unique challenges that require tailored support and so the enterprise support offered is the same as that given to the mainstream population. "We treat everyone the same" is a common cry from the enterprise agencies but in this instance, treating everyone the same is not the solution.

But entrepreneurs from minority and disadvantaged communities also face challenges that are exclusive to their specific community. For example, gay entrepreneurs must decide if they will 'come out' and let it be known publicly that the business is owned by someone from the gay community which may incite homophobic hate crime against the person or their business. Immigrants have a limited understanding of the entrepreneurial ecosystem in their host country and so are unaware of the legislation and supports regarding business start-ups. Both unemployed and disabled people suffer from the 'welfare benefit trap' and are afraid to start a business because they may lose the only stable income that they currently receive that enables them to survive. This issue has been highlighted by many studies and generally, it is not possible to leave the welfare system on a phased-basis which would be a welcome approach for these communities. Young people do not have work experience and have small business 
networks which are significant shortcomings when seeking to start one's own business. Each of these challenges that are exclusive to the specific communities, plus the distinctive challenges that are common across each of the minority communities, ensures that the entrepreneurial behaviour of entrepreneurs from these communities must be different to that experienced by entrepreneurs from mainstream society.

In seeking a solution to the issues faced by minority and disadvantaged entrepreneurs, policymakers need to consider adopting a new approach to the introduction of targeted initiatives. The normal process is either to introduce macro policies that will improve the general economic environment or micro policies that might include programs offering supports such as information, training, advice, access to finance, public procurement or export support. Cooney et al. (2018) suggested that a more holistic approach is required for people with disabilities and arguably this approach could also be applied to any minority or disadvantaged community.

Figure 1 - Funnel Approach to Policy

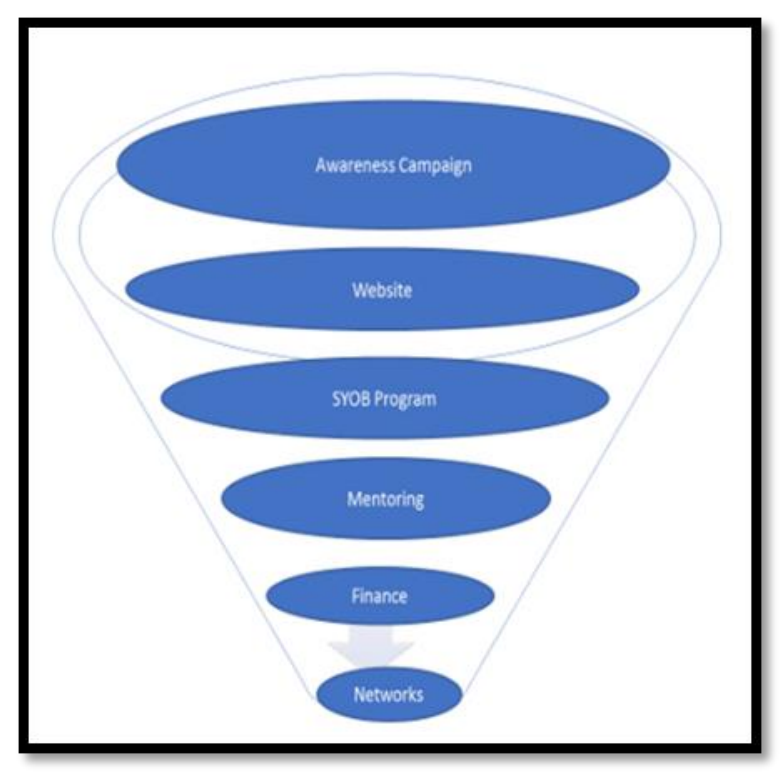

Source: Cooney, Kitching and Kaperova $(2018$, p5)

Figure 1 details the 'Funnel Approach' which suggests that when targeting a minority group, policymakers should begin by introducing an awareness campaign which highlights the opportunity and benefits of self-employment for nascent or potential entrepreneurs. This approach is to ensure that all members of the community being targeted are informed and understand that entrepreneurship is a realistic career option for them when considering their income-generating options. Once they are aware of entrepreneurship as a potential career option, they may wish to gather additional information and so 
a website that provides tailored information will need to be available. Should a person then wish to understand the mechanics of starting a business, then they should be able to avail of one of the Start Your Own Business programs that are widely available in many countries. Thereafter, should the potential entrepreneur wish to continue on their entrepreneurial journey and if they have received positive feedback regarding the sustainability of their business proposal from the program provider, then a tailored mentoring program should be available, where the mentors have been trained both in business and in the etiquette of working with people from minority and disadvantaged communities, and also where the recipients of the mentoring support can expect tailored understanding of their unique challenges. If the business proposal still has merit, then a ring-fenced fund of soft finance needs to be available as access to finance is a significant problem for minority and disadvantaged entrepreneurs. The final stage of the funnel is to create a network that enables entrepreneurs to learn from their peers. The major benefit of the 'Funnel Approach' is that it encourages all members of each community to become involved initially, but through a process of self-selection and business idea elimination, the numbers going through the funnel gradually get smaller and the costlier resources can be targeted at the points where numbers are fewer. For example, mentoring is costly and therefore there is widespread difficulty in sustaining such programs, but in this model only people who have been through the earlier stages will be eligible for mentoring and so the numbers involved should be small. However, the numbers would be largest at the initial awareness stage, but the costs involved would be relatively modest. This 'Funnel Approach' could also incorporate the existing ecosystem so that the burden on the exchequer is minimised.

Deakin (1996) described how a marginalised community can frequently find it difficult to divorce business from social living and how this can have both positive and negative connotations for an entrepreneur. On one hand, a social network is created and through this network contributions are made towards the sustenance of the business with increased profits and access to different markets. However, on the other hand, a business may also be considered solely as a trader for that community and not an entrepreneur derived from it. Entrepreneurship is a natural expression of personal enterprise, selfsufficiency and initiative (Morrison, 2000), yet it is also a means to financial gain which could suffer if a business were perceived as serving only the limited community from which it is derived. In recent times, there has been an increasing level of discussion by policymakers dealing with the topic of minority and disadvantaged entrepreneurship, but these dialogues have been weakened by the lack of proper understanding of what minority entrepreneurship represents. Appreciating the substantial differences in how different minority or disadvantaged communities should be considered could lead people to a 
greater enlightenment about the unique challenges that entrepreneurs from such communities might endure, plus these entrepreneurs will have encountered issues such as racism, ageism, homophobia or many of the other forms of prejudice that such communities must tolerate. Minority entrepreneurs also face challenges that mainstream entrepreneurs are less likely to have to shoulder. They have difficulties in raising finance to get the business started, either due to prejudice or because of a lack of collateral due to their circumstances. They are also less likely to have role models, an element to entrepreneurship that is highly underestimated. Research into minority entrepreneurs (Galloway and Cooney, 2012) has highlighted their greater lack of experience in managerial capacities and lower levels of educational achievement due to their social circumstances. People within these minority groups frequently suffer social marginalisation because of the intolerance and discrimination presented by mainstream society.

Fresh thinking is required by researchers, educators / trainers, enterprise support agencies and policymakers if people from minority and disadvantaged communities are to maximise their economic and social potential. A good starting point to fresh thinking would be to stop viewing these communities as social problems and instead to view them as opportunities for greater rates of entrepreneurial activity. Unfortunately, there is very limited research available which gives insights into the entrepreneurial behaviour of the entrepreneurs from minority and disadvantaged communities, and greater understanding is needed if policymakers are to design and deliver initiatives that are truly appropriate for their needs. There is significant opportunity within these field for researchers to undertake studies that will lead to greater understanding of their entrepreneurial behaviour, for educators and enterprise support agencies to deliver tailored support, and for policymakers to design policies and programs that reflect the unique challenges that entrepreneurs from these communities endure when starting a business. All participating stakeholders will enjoy the success of building an inclusive approach to entrepreneurial behaviour and the economic and societal well-being of our countries will also benefit. So, let's get started!

\section{References}

Andersson, L., \& Hammarstedt, M. (2015). Ethnic Enclaves, Networks and Self-Employment among Middle Eastern Immigrants in Sweden. International Migration, 53(6), 27-40.

Baker J.; Lynch, K.; Cantillon, S. and Walsh, J. (2004). Equality, From Theory to Action. Palgrave Macmillan, Basingstoke. 
Balcazar, F. E., Kuchak, J., Dimpfl, S., Sariepella, V., \& Alvarado, F. (2014). An empowerment model of entrepreneurship for people with disabilities in the United States. Psychosocial Intervention, 23(2), 145-150.

Bertelsmann Stiftung (2016). Responsible Entrepreneurship: Social Innovation through Entrepreneurial Action. Bertelsmann-Stiftung, Gütersloh.

Block, J., \& Koellinger, P. (2009). I can't get no satisfaction: Necessity entrepreneurship and procedural utility. Kyklos, 62(2), 191-209.

Boyce, C. J., Wood, A. M., Daly, M., \& Sedikides, C. (2015). Personality change following unemployment. Journal of Applied Psychology, 100(4), 991.

Branchik, B.J. (2002). Out in the market: A history of the gay market segment in the United States. Journal of Macromarketing, 22(1), 86-97.

Bridge, S., O’Neill, K., \& Cromie, S. (1998). Understanding enterprise, entrepreneurship and small firms. Macmillan, London.

Browning, M., \& Heinesen, E. (2012). Effect of job loss due to plant closure on mortality and hospitalization. Journal of Health Economics, 31(4), 599-616.

Buford, H. (2005). The gay market goes mainstream. The Gay Lesbian Review, 12(1), 22-24.

Bygrave, W. D., \& Hofer, C. W. (1992). Theorizing about entrepreneurship. Entrepreneurship Theory and Practice, 16(2), 13-22.

Caliendo, M., Fossen, F., \& Kritikos, A. S. (2014). Personality characteristics and the decisions to become and stay self-employed. Small Business Economics, 42(4), 787-814.

Carter, S., Mwaura, S., Ram, M., Trehan, K., \& Jones, T. (2015). Barriers to ethnic minority and women's enterprise: Existing evidence, policy tensions and unsettled questions. International Small Business Journal, 33(1), 49-69.

Castells, M. (1983). The City and the Grassroots. University of California Press, Berkeley.

Ceptureanu, S. I., \& Ceptureanu, E. G. (2015). Challenges and barriers of European young entrepreneurs. Management Research and Practice, 7(3), 34.

Chasin, A. (2000). Selling Out: The Gay and Lesbian Movement Goes to Market. St. Martin's Press, New York.

Chrysostome, E., \& Lin, X. (2010). Immigrant entrepreneurship: Scrutinizing a promising type of business venture. Thunderbird International Business Review, 52(2), 77-82.

Cooney, T. (2008). Entrepreneurs with Disabilities: Profile of a Forgotten Minority. Irish Business Journal, $4(1), 119-129$. 
Cooney, T.M.; Kitching, J. and Kasperova, E. (2018). Policy challenges in supporting entrepreneurs with disabilities: Exploring a funnel approach. Babson Conference, Waterford, June 6-9.

Deakin, N. (1996). The devils in the detail: some reflections on contracting for social care by voluntary organizations. Social Policy and Administration, 30(1), 20-38.

Deakins, D., Ishaq, M., Smallbone, D., Whittam, G., \& Wyper, J. (2007). Ethnic minority businesses in Scotland and the role of social capital. International Small Business Journal, 25(3), 307-326.

Desiderio, M. V., \& Salt, J. (2010). Main findings of the conference on entrepreneurship and employment creation of immigrants in OECD countries. OECD Conference, Paris, June 9-10.

Dodd, S. D., Pret, T., \& Shaw, E. (2016). Advancing understanding of entrepreneurial embeddedness: forms of capital, social contexts and time. In 'A research agenda for entrepreneurship and context' (Editors - Welter, F., \& Gartner, W. B.). Edward Elgar Publishing., Cheltenham, pp120-133.

Doyel, A. W. (2000). No more job interviews!: Self-employment strategies for people with disabilities. St. Augustine, FL: Training Resource Network.

Drucker, P. F. (1985). The discipline of innovation. Harvard Business Review, 63(3), 67-72.

Elo, M., Sandberg, S., Servais, P., Basco, R., Cruz, A. D., Riddle, L., \& Täube, F. (2018). Advancing the views on migrant and diaspora entrepreneurs in international entrepreneurship. Journal of International Entrepreneurship, 1-15.

Eurofound (2011). Emerging forms of entrepreneurship. Eurofound, Dublin.

European Foundation for the Improvement of Living and Working Conditions. (2015). First Findings: Sixth European Working Conditions Survey: Résumé. EuroFound, Dublin.

European Commission (2015). Policy Brief on Sustaining Self-employment. European Commission, Brussels.

European Commission (2016). Promoting and Supporting Migrant Entrepreneurship. European Commission, Brussels.

Eurostat (2018). News Release: Eurolndicators 34/2018. Eurostat Press Office, Luxembourg.

Fatoki, O. (2014). The impact of managerial competencies on the performance of immigrant-owned enterprises in South Africa. Mediterranean Journal of Social Sciences, 5(6), 141.

Foster, S. (2010). Promoting Entrepreneurship among Disabled People with Visual Impairment. Royal National College for the Blind, Hereford.

Fritsch, M., Kritikos, A., \& Pijnenburg, K. (2015). Business cycles, unemployment and entrepreneurial entry-evidence from Germany. International Entrepreneurship and Management Journal, 11(2), 267-286. 
Fry, A. (1997). Reaching the pink pound. Marketing, $4^{\text {th }}$ September 23-26.

Galloway, L., \& Cooney, T. M. (2012). Introduction. International Journal of Entrepreneurship and Innovation, 13(2), 77-79.

Gartner, W. B. (1988). "Who is an entrepreneur?" is the wrong question. American Journal of Small Business, 12(4), 11-32.

GEM (2005). Global Entrepreneurship Monitor: 2005 Global Report. Babson College, Wellesley, MA.

GEM (2015). Future Potential: A GEM perspective on youth entrepreneurship 2015. Babson College, Wellesley, MA.

GEM (2016). Global Entrepreneurship Monitor: 2015/16 Global Report. Babson College, Wellesley, MA.

Grandin, T., \& Duffy, K. (2008). Developing talents: Careers for individuals with Asperger syndrome and high-functioning autism. AAPC Publishing, Shawnee, KS.

Jones, M. and Latreille, P. (2011). Disability and Self-employment: Evidence for the UK. Applied Economics, 43(27), 4161-4178.

Jones, T., Ram, M., Edwards, P., Kiselinchev, A., \& Muchenje, L. (2014). Mixed embeddedness and new migrant enterprise in the UK. Entrepreneurship \& Regional Development, 26(5-6), 500-520.

Kidney, E. and Cooney, T.M. (2014). The Gay Connection: Exploring the Cultural Capital of Gay Entrepreneurs, International Council for Small Business Conference, June 11-14, Dublin

Kitching, J. (2013). Entrepreneurship and disability. OECD, Paris.

Kouriloff, M. (2000). Exploring Perceptions of a Priori Barriers to Entrepreneurship: A Multidisciplinary Approach. Entrepreneurship Theory and Practice, 25(2), 59-79.

Krugman, P. (1996). How the economy organizes itself in space: a survey of the new economic geography (Working Paper No. 96-04-021). Santa Fe Institute, NM.

Lai, D. W., Li, L., \& Daoust, G. D. (2017). Factors influencing suicide behaviours in immigrant and ethnocultural minority groups: A systematic review. Journal of Immigrant and Minority Health, 19(3), 755768.

Lechner, M. and Vazquez-Alvarez, R. (2011). The Effect of Disability on Labour Market Outcomes in Germany. Applied Economics, 43(8), 389-412.

Levin, S. (1998). In the pink: The making of successful gay- and lesbian-owned businesses. Haworth Press, New York.

Lewis, K., \& Massey, C. (2003). Youth entrepreneurship and government policy. New Zealand Centre for SME Research, Massey University, 14. 
Light, I. \& Bhachu, P. (Ed.). (2017). Immigration and entrepreneurship: culture, capital, and ethnic networks. Routledge, London.

Llisterri, J. J., Kantis, H., Angelelli, P., \& Tejerina, L. (2006). Is Youth Entrepreneurship a Necessity or an Opportunity?: A first exploration of household and new enterprise surveys in Latin America. InterAmerican Development Bank.

Lukenbill, G. (1995). Untold Millions. Harper Business, New York.

Maritz, A., \& Laferriere, R. (2016). Entrepreneurship and self-employment for people with disabilities. Australian Journal of Career Development, 25(2), 45-54.

Marlow, S., Greene, F. J., \& Coad, A. (2018). Advancing gendered analyses of entrepreneurship: A critical exploration of entrepreneurial activity among gay men and lesbian women. British Journal of Management, 29(1), 118-135.

Masurel, E., Nijkamp, P., \& Vindigni, G. (2004). Breeding places for ethnic entrepreneurs: a comparative marketing approach. Entrepreneurship \& Regional Development, 16(1), 77-86.

McQuillan, H. (2013). Self-Employment Options for People with a Disability: Good Practice Review. Brothers of Charity, Clare.

Meager, N. and Higgins, T. (2011). Disability and Skills in a Changing Economy. UK Commission for Employment and Skills, Briefing Paper Series, London.

Minola, T., Criaco, G. and Cassia, L. (2014). Are youth really different? New beliefs for old practices in entrepreneurship. International Journal of Entrepreneurship and Innovation Management, 18(2/3), 233-259.

Morrison, A. (2000). Entrepreneurship: what triggers it? International Journal of Entrepreneurial Behavior \& Research, 6(2), 59-71.

Naudé, W., Siegel, M., \& Marchand, K. (2015). Migration, entrepreneurship and development: A critical review. UNU-MERIT Working Paper No. 033, Maastricht.

Ndofor, H. \& Priem, R. (2011). Entrepreneur's forms of capital, venture strategy and venture performance: The case of immigrant entrepreneurs. Journal of Management, 37(3): 790-818.

OECD (2010). Shooting for the Moon: Good Practices in local youth entrepreneurship support. OECD, Paris.

OECD (2011). Migrant Entrepreneurship in OECD Countries. OECD, Paris

OECD (2013). The Missing Entrepreneurs 2013: Policies for Inclusive Entrepreneurship. OECD Publishing, Paris.

OECD (2014a). The Missing Entrepreneurs 2014: Policies for Inclusive Entrepreneurship. OECD Publishing, Paris. 
OECD (2014b). Entrepreneurial Activities in Europe-Entrepreneurship for People with Disabilities (No. 6). OECD, Paris.

OECD (2015). The Missing Entrepreneurs 2017: Policies for Inclusive Entrepreneurship. OECD Publishing, Paris.

OECD (2017). The Missing Entrepreneurs 2017: Policies for Inclusive Entrepreneurship. OECD Publishing, Paris.

Pagán, R. (2009). Self-employment among people with disabilities: evidence for Europe. Disability \& Society, 24(2), 217-229.

Parker Harris, S., Renko, M., \& Caldwell, K. (2014). Social entrepreneurship as an employment pathway for people with disabilities: exploring political-economic and socio-cultural factors. Disability \& Society, 29(8), 1275-1290.

Peroni, C., Riillo, C. A., \& Sarracino, F. (2016). Entrepreneurship and immigration: evidence from GEM Luxembourg. Small Business Economics, 46(4), 639-656.

Prince, J.P. (1997). Career Assessment with Lesbian, Gay, and Bisexual Individuals. Journal of Career Assessment, 5(2), 225-238.

Redien-Collot, R. (2012). Motivations of gay entrepreneurs: A focus on the construct of appropriateness. International Journal of Entrepreneurship and Innovation, 13(2), 115-1241.

Renko, M., Parker Harris, S., \& Caldwell, K. (2016). Entrepreneurial entry by people with disabilities. International Small Business Journal, 34(5), 555-578.

Reynolds, P.D.; Bygrave, W.D.; Autio, E.; Cox, L.W. and Hay, M. (202). Global Entrepreneurship Monitor Executive Report. Babson College, Wellesley.

Rozali, N., Abdullah, S., Ishak, S. I. D., Azmi, A. A., \& Akhmar, N. H. (2017). Challenges faced By People with Disability for Getting Jobs: Entrepreneurship Solution for Unemployment. International Journal of Academic Research in Business and Social Sciences, 7(3), 333-339.

Scase, R., \& Goffee, R. (1980). The real world of the business owner. Croom Helm, London.

Schindehutte, M., Morris, M., and Allen, J. (2005). Homosexuality and Entrepreneurship: Implications of the gay identity for the venture-creation experience. Journal of Entrepreneurship and Innovation, 6(1), 27-40.

Schoof, U. (2006). Stimulating Youth Entrepreneurship: Barriers and incentives to enterprise start-ups by young people (No. 993881573402676). International Labour Organization.

Schumpeter, J. A. (1934). Change and the Entrepreneur. Essays of JA Schumpeter. 
Sender, K. (2004). Business, not politics: The making of the gay market. Columbia University Press, New York.

Shapero, A. (1971). An action program for entrepreneurship. Multi-Disciplinary Research, Austin.

Shinnar, R. S., \& Young, C. A. (2008). Hispanic immigrant entrepreneurs in the Las Vegas metropolitan area: motivations for entry into and outcomes of self-employment. Journal of Small Business Management, 46(2), 242-262.

Stevenson, L., \& Lundström, A. (2001). Patterns and trends in entrepreneurship/SME policy and practice in ten economies (Vol. 3). Vällingby, Sweden: Elanders Gotab.

Tamásy, C., \& Diez, J. R. (2016). Regional resilience, economy and society: Globalising rural places. Routledge, London.

Tilcsik, A. (2011). Pride and prejudice: Employment discrimination against openly gay men in the United States. American Journal of Sociology, 117(2), 586-626.

Timmons, J. A., Spinelli, S., \& Tan, Y. (1994). New venture creation: Entrepreneurship for the 21st century. Irwin, Burr Ridge, IL.

Varnell, P. (2001). What gay entrepreneurs contribute. Chicago Free Press, Chicago, IL.

Waldinger, R. D., Aldrich, H., \& Ward, R. (1990). Ethnic entrepreneurs: Immigrant business in industrial societies (Vol. 1). Sage Publications, Inc.

Wang, Y., \& Warn, J. (2018). Chinese immigrant entrepreneurship: Embeddedness and the interaction of resources with the wider social and economic and context. International Small Business Journal, 36(2), 131-148

Watkins, J. M., \& Watkins, D. S. (1983). The female entrepreneur: her background and determinants of business choice-some British data. Frontiers of Entrepreneurship Research, 271-288, Babson College, Wellesley, MA.

WHO (2014). World Report on Disability. World Health Organisation, Geneva.

Wilkinson, S., and Kitzinger, C. (1994). The social construction of heterosexuality. Journal of Gender Studies, 3(3), 307-316.

Willsdon, J., 2006. Gay Entrepreneurs, Different but the Same. Irish Journal of Management, 26(1), 107121.

Wood, L. (1999). Think pink! Attracting the pink pound. Insights, A107-A110.

Wood, G.J.; Davidson, M.J. and Fielden, S.L. (2012). Minorities in Entrepreneurship: An International Review. Edward Elgar Publishing, Cheltenham. 
Zouhar, J., \& Lukes, M. (2015). Factors influencing nascent entrepreneurship of the unemployed: The role of labor market policies. In Academy of Management Proceedings (Vol. 2015, No. 1, p. 18476). Briarcliff Manor, NY 10510: Academy of Management. 